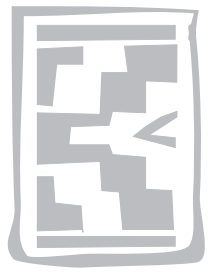

\title{
The performance of Orma Boran and Maasai Zebu crossbreeds in a trypanosomosis endemic area of Nguruman, south western Kenya
}

\author{
M.W. MAICHOMO'1, J.M. NDUNG'U', P.M. NGARE' ${ }^{1}$ and I.M. OLE-MAPENAY²
}

\begin{abstract}
MAICHOMO, M.W., NDUNG'U, J.M., NGARE, P.M. \& OLE-MAPENAY, I.M. 2005. The performance of Orma Boran and Maasai Zebu crossbreeds in a trypanosomosis endemic area of Nguruman, south western Kenya. Onderstepoort Journal of Veterinary Research, 72:87-93

Studies on the trypanotolerance of Orma Boran X Maasai Zebu (Orma Zebu) crossbred cattle $\left(F_{1}\right.$ progeny) and pure-bred Maasai Zebu contemporaries were carried out in Nguruman, south western Kenya. The two groups were monitored from birth for a period of 2 years. The incidence of trypanosomosis, parasitaemia, packed cell volume (PCV), body mass and average daily mass gain were monitored. During the study period, overall trypanosomosis incidence was low (3\%). The crossbred cattle had a higher incidence of infection (61\% vs $39 \%$ ). The mean PCV and mean mass gain for the crossbred cattle was higher than that of the Maasai Zebu. The mean calf body mass at weaning (8 months) for the Orma Zebu and Maasai Zebu was $72 \mathrm{~kg}$ and $64 \mathrm{~kg}$, respectively, while at 18 months of age their mean body mass was $164 \mathrm{~kg}$ and $123 \mathrm{~kg}$, respectively. During the rainy season significant differences in average daily mass gains were noted $(P<0.05)$. The superior mass gain of the Orma Zebu observed during the rainy season, despite higher infection rates, indicate an enhanced trypanotolerance. Moreover, the better performance of the Orma Zebu is an attribute that could be exploited in the adoption of the trypanotolerance genotype, as a sustainable trypanosomosis control strategy.
\end{abstract}

Keywords: Cattle, productivity, Maasai Zebu, Orma Boran, Orma Zebu, trypanotolerance

\section{INTRODUCTION}

Vast areas of sub-Saharan Africa are not used for cattle production because of tsetse-transmitted trypanosomosis. Thirty-seven percent of the continent, some 11 million $\mathrm{km}^{2}$ involving 40 countries, is infested with tsetse (FAO/WHO/OIE 1982), $65 \%$ of which (7 million $\mathrm{km}^{2}$ ) could be used for livestock or mixed agricultural development without stress to the environment if trypanosomosis was controlled (MacLennan 1980). Africa has $11 \%$ of the world's cattle population and $26 \%$ of the world's small

1 Kenya Trypanosomiasis Research Institute (KETRI), P.O. Box 362, Kikuyu, Kenya

2 University of Nairobi, Department of Public Health, Pharmacology and Toxicology, P.O. Box 29053, Nairobi, Kenya

Accepted for publication 28 September 2004-Editor ruminant population. Ruminants form $82 \%$ of total livestock biomass in Africa (Jordan 1986; d'leteren 1994). The sub-humid zones, comprising $22 \%$ of the landmass, account for $20 \%$ of the ruminant population, whereas the humid zones, with $19 \%$ of the landmass, account for only $6 \%$. It is thus in the sub-humid and non-forested portions of the humid zone that the potential for expansion of livestock production is highest (Winrock International 1992).

Trypanosomosis is regarded as the single most significant constraint to animal agriculture in the subhumid and non-forested portions of the humid zone of Africa. The disease has both direct and indirect economic impacts on livestock production (Murray, Stear, Trail, d'leteren, Agyemang \& Dwinger 1991). The direct impacts are associated with losses in milk and meat production, mortality and morbidity. 
The indirect impact is related to the cost of land and other resources which are currently not used for livestock production because of the presence of tsetse flies, as well as lower crop productivity due to reduced animal traction and less manure to fertilise the soil (Swallow 1997). To cater for an ever-increasing human population in Africa, there is need for concerted efforts to step up meat and milk production to offset an already existing deficit. Control of trypanosomosis will have important benefits for animal health and as such, offer an important avenue for farmers to increase their food security and incomes (McDermott, Randolf \& Staal 1999).

In pastoral areas, traditional grazing patterns which avoid vector habitats have been used successfully, and hence reduce the infection rates. This has however been possible only when climatic conditions and pasture availability are good. In times of drought, the survival strategy by livestock keepers has been to move their animals to bushy areas that harbour the tsetse vectors, resulting in increased disease incidence. The use of trypanocidal drugs is the main trypanosomosis control strategy in sub-Saharan Africa, and approximately 35 million doses are sold annually. However, the incidence of trypanosome resistance to treatment is increasing and expanding (Peregrine 1994). Fortunately, in sub-Saharan Afri$\mathrm{ca}$, the use of trypanotolerant animals can be used to reduce drug use.

Keeping of trypanotolerant breeds of cattle which require little or no chemotherapy, has been viewed as a sustainable approach to livestock development in the tsetse infested parts of Africa (Njogu, Dolan, Wilson \& Sayer 1985; Murray, Trail \& d'leteren 1990). Trypanotolerance has been demonstrated in the Orma Boran breed of cattle which is large in size and was originally kept by the Orma people of Tana River district (Njogu et al. 1985; Wilson, Gatuta, Mgutu \& Alushula 1986; Irungu, Nyamwaro, Alushula, Rege \& Dolan 1999). The ability of the East African Maasai Zebu (Mwangi, Stevenson, Gettinby, Reid \& Murray 1998) to control parasitaemia and maintain production, even when infected, has been reported. When compared with the improved Kenyan Boran breed, the Orma Boran has lower trypanosome infection rates and, if not treated, shows better control of anaemia and decreased mortality (Njogu et al. 1985).

The overall productivity of the Maasai Zebu is relatively low compared to the existing demand for food. It is possible that this could be improved by exploiting genetic potential of other indigenous breeds such as the Orma Boran, while sustaining its resistance to trypanosomosis.
This study was therefore designed to evaluate the performance traits achieved by Maasai Zebu and Orma Boran crosses maintained in the pastoral region of Nguruman, an endemic trypanosomosis area.

\section{MATERIALS AND METHODS}

\section{Study area}

Olkiramatian and Shompole group ranches are in Magadi division, Kajiado district of south western Kenya. It is a semi-arid area, with scanty savannah vegetation and thick bushes near the Nguruman escarpment. During the rainy season, the pasture is plentiful, but short-lived, and is variable from region to region in the district. Widespread stony terrain hinders easy movement by animals and it has a poor water holding capacity.

\section{The Orma Zebu crossbreed}

An Orma Boran breeding herd was established by the Kenya Trypanosomosis Research Institute (KETRI) in 1985 on Galana ranch, a tsetse-infested coastal region of Kenya, and selected for trypanotolerance during a period of over 12 years. Twelve bulls were transferred to the Nguruman study area in June 1996, as part of a technology transfer programme. Acceptance of the breed by the Nguruman community was good, as revealed by a participatory rural appraisal (PRA) exercise. The Orma Boran bulls were managed in a pastoral set-up together with Maasai Zebu cattle. They were allowed to crossbreed freely resulting in Orma Boran-Maasai Zebu (Orma Zebu) crosses, which have been monitored for growth, performance traits and incidence of trypanosomosis. Where possible, a Maasai Zebu calf born during the same period as an Orma Zebu cross calf was identified as a control. The study and control groups were subsequently monitored every month for mass gain, body condition and trypanosomosis infection rates using routine procedures.

\section{Study design and sampling procedure}

A longitudinal study design was used, comparing important performance traits and trypanosomosis incidence between the Maasai Zebu and the Orma Zebu crosses. Purposive sampling of Orma Zebu cross calves was done based on prior knowledge by the farmer that the Orma Boran bull was the sire. Corresponding Maasai Zebu cohorts were selected if they were born within the same month as the Orma Zebu crosses. As soon as calving was reported by 
the farmer, the calves were ear-tagged with appropriate labels indicating breed and animal number, while other details were maintained in a record sheet. All animals were kept under a pastoral management system.

Five herds belonging to different farmers were identified and kept in different grazing points according to farmer distribution. The nature of the study necessitated that the calves had different entry dates according to their respective dates of birth, hence age varied considerably across all the sample units. The two cohorts were monitored monthly for 2 years with equal rigor, minimizing withdrawal of sampling units to compare growth performance parameters and trypanosomosis incidence. This included the body mass and subjective body condition estimation on a nine point scale. Blood was subsequently collected from the ear vein, and after PCV estimation, the presence of trypanosomes was determined using the buffy coat technique as described by Murray \& Urquhart (1977). Animals found positive were treated with diminazene aceturate at a dosage rate of $7 \mathrm{mg} / \mathrm{kg}$ body mass. Any animals that died or were removed from the study through sale, gifts or exchanges were noted.

\section{Data preparation}

Individual records were built up for each calf, including sex, date of birth, dam number, sire number, herd number, herd location, calf number, calf registration date and birth mass, calf colour and special identification marks. Calf weaning age was assumed to be 9 months and weaning mass was estimated from this. From the data, growth rate and mean calf body mass changes from birth to 23 months were calculated. Growth rate was obtained by regressing body mass on age.

\section{Data management and analysis}

Herd management and seasonal factors affecting growth, including associations between productivity and trypanosomosis, were investigated. The effects of breed and environment on production parameters and health were analyzed by least squares procedures. Explanatory factors such as breed, sex, pasture availability, location of herd and age category were investigated for their influence on the growth rate, using general linear models (GLM). Three seasons, i.e. severe drought, rainy season and moderate drought, depicted pasture availability. Age was categorized as calves (up to 8 months), young adults (9-18 months) and adult cattle (18 months or more). Tests of significance associated with linear contrasts between group means were done by mean squares (Analysis of Variance) and the $T$ test procedure. Significance was accepted at $P \leq 0.05$. Breed predisposition to trypanosomosis was assessed by chi-square using $2 \times 2$ Table format.

\section{RESULTS}

\section{Trypanosomosis incidence and packed cell volume (PCV)}

A total of 133 crossbred calves and 30 Maasai Zebu controls were monitored over a 2-year period. Three percent of all animals were infected and the prevalence of Trypanosoma congolense and Trypanosoma vivax was not significantly different ( $48.2 \%$ vs $51.8 \%$, respectively). However, during the rainy season, the prevalence of trypanosomosis differed significantly between the Orma Zebu and the Maasai Zebu $\left(\chi^{2}, 5.86 ; P=0.0155\right)$ as shown in Table 1. Consequently, there was an increase in disease incidence $(47.4 \%)$ during the rainy season; the incidence being higher in males $(66.7 \%)$ than in females $(33.3 \%)$.

Generally, the Orma Zebu crosses had slightly higher but significant PCV $(29.4 \%$ vs $28.4 \%$; $P=$ $0.0013)$ than the Maasai Zebu. Striking differences in PCV between infected and non-infected animals regardless of breed were obtained (18.8\% vs $26.9 \% ; P=0.0000)$. However, a difference in PCV between infected Maasai Zebu and Orma Zebu was detected in pre-weaned calves (24.9\%; $27.3 \%$ ) although this is insignificant. A significant breed difference in PCV was observed when the rainy season and age were considered. This was often higher in the Orma Zebu crosses, except in the weaned group. High PCV values were also observed in herds found in areas with poor pasture but low trypanosomosis incidence.

\section{Growth rate}

The mean mass gain of all calves from birth to 23 months of age is illustrated in Fig. 1. The Orma Zebu crossbreeds had a consistently higher mean body mass except at 11.5 months when they were equal to that of the Maasai Zebu controls. The mean birth mass of Orma Zebu was $25.8 \mathrm{~kg}$ (Table I) and thereafter sustained a good body condition that was highly appreciated by the Maasai pastoralist community. It was not possible to get the birth mass for the Maasai Zebu due to late reporting of births. Larger differences in body mass were observed at 
Orma Boran and Maasai Zebu crossbreeds in trypanosomosis endemic area, Kenya

TABLE 1 Overall body mass, packed cell volume (PCV) and daily mass gain in Orma Zebu and Maasai Zebu cattle

\begin{tabular}{|c|c|c|c|c|c|}
\hline Trait & Age & Breed & Mean value & SD & SE \\
\hline Body mass $(\mathrm{kg})^{\star \star a}$ & $\begin{array}{l}\text { At birth } \\
9 \text { months } \\
18 \text { months }\end{array}$ & $\begin{array}{l}\text { Orma Zebu } \\
\text { Maasai Zebu } \\
\text { Orma Zebu } \\
\text { Maasai Zebu } \\
\text { Orma Zebu } \\
\text { Maasai Zebu }\end{array}$ & $\begin{array}{l}25.8 \\
- \\
79 \\
71 \\
164 \\
123\end{array}$ & $\begin{array}{l}5.76 \\
- \\
18 \\
17 \\
34 \\
26\end{array}$ & $\begin{array}{l}0.78 \\
- \\
1.3 \\
2.3 \\
4.2 \\
4.5\end{array}$ \\
\hline Packed cell volume (\%) & $\begin{array}{l}9 \text { months } \\
18 \text { months }\end{array}$ & $\begin{array}{l}\text { Orma Zebu } \\
\text { Maasai Zebu } \\
\text { Orma Zebu } \\
\text { Maasai Zebu }\end{array}$ & $\begin{array}{l}27.9 \\
27.7 \\
26.1 \\
28.1\end{array}$ & $\begin{array}{l}4.2 \\
5.3 \\
3.1 \\
3.6\end{array}$ & $\begin{array}{l}0.9 \\
0.7 \\
0.7 \\
1.1\end{array}$ \\
\hline Daily mass gain(kg) & $\begin{array}{l}\text { Birth to } 9 \text { months } \\
\text { 9-18 months } \\
>18 \text { months }\end{array}$ & $\begin{array}{l}\text { Orma Zebu } \\
\text { Maasai Zebu } \\
\text { Orma Zebu } \\
\text { Maasai Zebu } \\
\text { Orma Zebu } \\
\text { Maasai Zebu }\end{array}$ & $\begin{array}{l}0.2525 \\
0.2385 \\
\\
0.2267 \\
0.2818 \\
0.0598 \\
0.0823\end{array}$ & $\begin{array}{l}0.1930 \\
0.2132 \\
0.2359 \\
0.2198 \\
0.2863 \\
0.2307\end{array}$ & $\begin{array}{l}0.009 \\
0.019 \\
\\
0.0556 \\
0.0153 \\
\\
0.0367 \\
0.0444\end{array}$ \\
\hline Trypanosomosis prevalence (\%) & During rainy season & $\begin{array}{l}\text { Orma Zebu } \\
\text { Maasai Zebu }\end{array}$ & $\begin{array}{l}1.713 \\
1.287\end{array}$ & $\begin{array}{l}- \\
-\end{array}$ & $\begin{array}{l}- \\
-\end{array}$ \\
\hline
\end{tabular}

a At the age of 18 months, the Orma Zebu had a significantly higher body mass than the Maasai Zebu

** Body mass was often higher during the rainy season

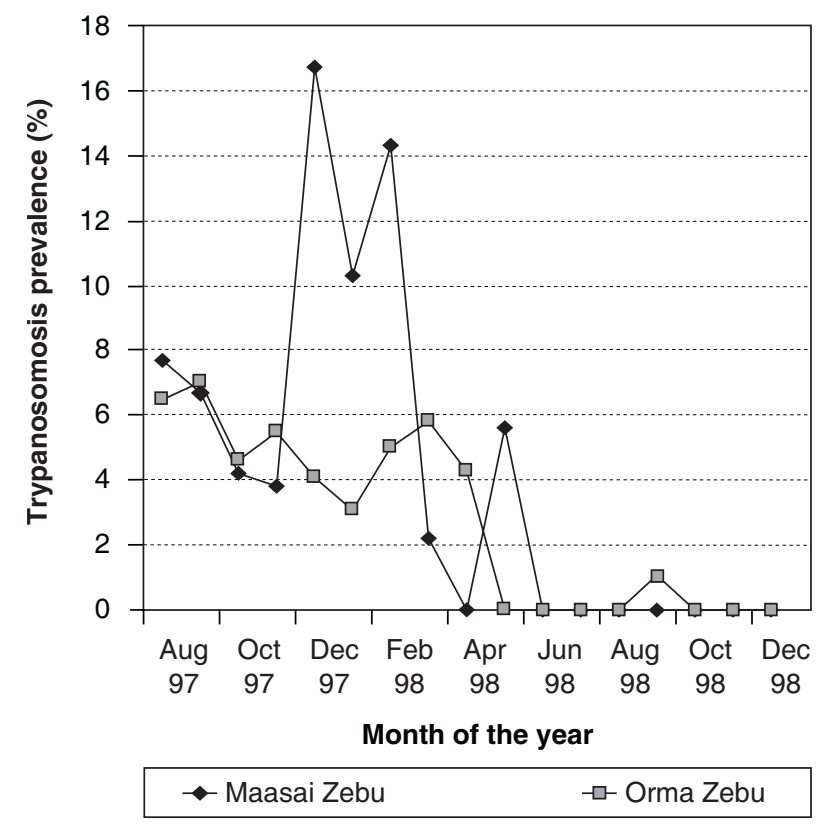

FIG. 1 Trypanosomosis prevalence for both the Maasai Zebu and Orma Zebu calves from Aug 1997 to Dec 1998

18 months with the Orma Zebu outweighing the Maasai Zebu on average by approximately $40 \mathrm{~kg}$ (163.5 kg vs $123.2 \mathrm{~kg}$ ).

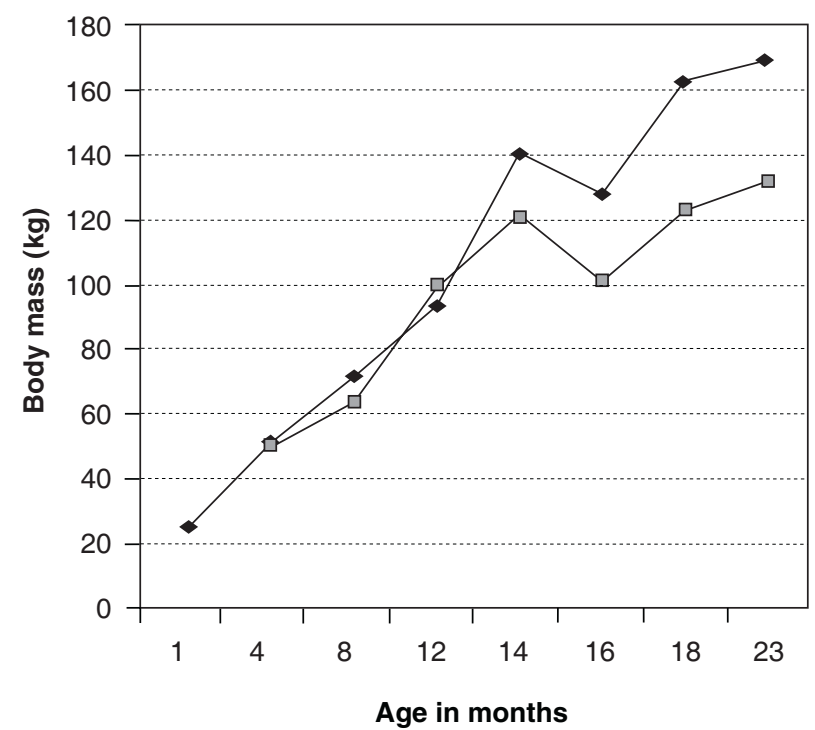

$\bullet$ Orma Zebu $\quad \neg-$ Maasai Zebu

FIG. 2 Comparative body mass changes between the Orma Zebu and Maasai Zebu animals in Kajiado district

Differences in average daily mass gain observed between the Maasai Zebu and Orma Zebu were insignificant $(0.216 \mathrm{~kg} ; 0.207, P=0.8078)$ but the 
TABLE 2 Effects of animal and environmental factors on daily mass gain in Orma Zebu and Masaai Zebu cattle. The general model failed to identify the significance of breed (genetic factor) as an important influence on growth rate

\begin{tabular}{|l|l|l|l|l|}
\hline Source & NDF & DDF & TYPE III F & Pr $>F^{\mathrm{c}}$ \\
\hline Breed & 1 & 1760 & 0.87 & 0.3515 \\
Sex & 1 & 1760 & 1.56 & 0.2122 \\
Season & 2 & 1760 & 37.12 & 0.0001 \\
Age & 2 & 1760 & 5.27 & 0.0052 \\
Locality $_{\text {Season/ herd location }}^{\mathrm{d}}$ & 4 & 1764 & 17.56 & 0.0001 \\
\hline
\end{tabular}

a NDF = Numerator Degrees of Freedom

b DDF = Denominator Degrees of Freedom

c $\mathrm{Pr}>\mathrm{F}=$ Probability greater than the $\mathrm{F}$ value

d Season/herd location interaction term

TABLE 3 Effects of animal and environmental factors on daily mass gain during the rainy season

\begin{tabular}{|l|l|l|l|l|}
\hline Source & NDFa & DDF $^{\mathrm{b}}$ & TYPE III F & Pr $>F^{\mathrm{c}}$ \\
\hline Breed $^{*}$ & 1 & 969 & 4.41 & 0.0360 \\
Sex & 1 & 969 & 5.49 & 0.0194 \\
Age & 1 & 969 & 2.28 & 0.1314 \\
Locality & 4 & 969 & 22.8 & 0.0001 \\
\hline
\end{tabular}

a NDF = Numerator Degrees of Freedom

b $\mathrm{DDF}=$ Denominator Degrees of Freedom

c $\operatorname{Pr}>\mathrm{F}=$ Probability greater than the $\mathrm{F}$ value

* Breed significantly affected growth rate during the rainy season

Orma Zebu crosses, regardless of age group, gained $14 \mathrm{~g}$ daily above the Maasai Zebu $(P=0.0360)$ during the rainy season. Between 2 and 9 months of age, the Orma Zebu crossbreeds gained 31g/day more than the Maasai Zebu (SE $=15, P=0.036$ ) while weaned Maasai Zebu calves gained $59 \mathrm{~g} /$ day more than the Orma Zebu crosses (Table I). Significance of breed was only realized during the rainy season when pasture was good and Orma Zebu crosses gained $31 \mathrm{~g} /$ day more than the Maasai Zebu $(P=0.0360)$. Males grew faster at a rate of $30 \mathrm{~g} /$ day more than females $(P=0.0194)$. These results emphasize the value of Orma Boran trypanotolerance during high tsetse challenge.

\section{Statistical analysis for factors influencing growth}

Evaluation of interaction effects between season and age enabled identification of significant differences in body mass and average daily gain (ADG) for both breeds (Tables 2 and 3). From GLM results, independent variables season $(P=0.001)$, age $(P=$ 0.001), farmer location $(P=0.001)$ and season/ farmer interaction $(P=0.001)$ generally enhanced ADG (Table 2). However, during the rainy season, breed $(P=0.036)$ and sex $(P=0.0194)$ became sig- nificant explanatory variables of average daily gain (Table 3). Pasture growth, which was better in the rainy season and poor in the dry season varied from region to region, and hence mass gain varied considerably according to pasture quality. Importance of rainfall and pasture availability was demonstrated by a net mass gain of $85 \mathrm{~g} /$ day higher compared to the dry season ( $S E=11, P=0.0001)$. The presence of good pasture overrode the effects of trypanosomosis. It was determined that animal herds maintained on good pasture where the trypanosomosis incidence was high gained $60 \mathrm{~g} /$ day more than their contemporaries on poor pastures. The average daily gain ranged between $183.6 \mathrm{~g} /$ day and $230 \mathrm{~g} /$ day when trypanosomosis prevalence was lower and pasture was good.

\section{DISCUSSION}

Superiority of genetic potential on growth and susceptibility to trypanosomosis has been highlighted in a number of ways in this study. The Orma Zebu crosses had higher body mass and average daily gain, and better body condition as well as higher PCV when infected compared to the Maasai Zebu controls. These observations reflect the ability of the 
Orma Zebu crosses to control PCV and hence contain anaemia and are in agreement with the observations made by Trail, d'leteren \& Murray (1991) in trypanotolerant animals. Significant differences in mean PCV between the Maasai Zebu and the Orma Zebu crossbreed in this study contrast with previous observation by Mwangi et al. (1998) who reported that the Maasai Zebu was superior. It is likely that the different intensities of tsetse challenge encountered in the two studies contributed to the differences reflected. However, there is agreement shown with the observation made by Njogu et al. (1985) that the Orma Boran was able to maintain PCV under natural tsetse challenge better than the Galana Boran. There is evidence that trypanotolerance is associated with the ability of the infected host to resist development of anaemia and control parasitaemia (Murray et al. 1977; Dargie, Murray, Grimshaw \& Mclntyre 1979; Akol, Authie, Pinder, Moloo, Roelants, \& Murray 1986; Paling, Moloo, Scott, Gettinby, McOdimba, Logan-Henfrey, Murray \& Williams 1991).

In the present study generally unimportant environmental and genetic factors became significant during the rainy season in the way they affected growth and other production traits. Importance of rainfall associated with good pasture growth and water availability particularly in pastoral areas under agro ecological zone $\mathrm{V}$ and above is paramount. There is a direct correlation between pasture availability and body mass, celeris peribus, as was shown by both the Maasai Zebu and Orma Zebu crosses. The growth rate observed during the rainy season compared favourably with that obtained in a previous study on Olkiramatian group ranch by Mwangi et al. (1998). The fact that the Orma Zebu gained $30 \mathrm{~g} /$ day more than the Maasai Zebu during the EI Nino rains, yet had significantly higher infection rates $(\mathrm{SE}=3, P$ $=0.0194$ ), could be an indicator of their enhanced trypanotolerance compared to that of the Maasai Zebu.

There is evidence that populations of Boran cattle (a sub-set of Zebu) reared in tsetse free areas can achieve higher levels of productivity than the trypanotolerant N'Dama cattle of West and Central Africa kept in medium to high trypanosomosis risk areas (Trail, Sones, Jibbo, Durkin, Light, \& Murray 1985). When the Boran cattle are maintained by chemoprophylaxis in high challenge areas, they have a superiority of $35 \%$ over the N'Dama cattle under similar challenge but without chemoprophylaxis. This gives hope that the Boran cattle types in East Africa can be used to exploit tsetse-infested regions, in order to increase agricultural productivity, food security and poverty alleviation. Furthermore, with the observation that there is some degree of resistance in the Orma Boran, selective upgrading of trypanotolerant, less productive cattle breeds such as the Maasai Zebu could improve on productivity.

The effect of trypanosomosis on growth was insignificant except during the rainy season but differed significantly between individual herds. Pastoralists are migratory in nature and employ strategic animal movement and chemotherapy to control trypanosomosis. The dismal effect that infection had on growth rate could be due to treatment administered to sick animals and the migration of animals to safer grounds, away from the tsetse flies.

This study has highlighted the superiority of Orma Zebu crosses in terms of higher body mass, growth rate, moderation of PCV to control anaemia when infected and better body condition associated with psychological satisfaction of the owner. The significance of the results obtained is probably reduced by harsh environmental conditions, presence of tickborne diseases that were confounding, fast treatment of infected animals. However, the sample size was more than 30 and the central limit theory indicates that the findings obtained can be extrapolated to the target population of concern. It will be of great value to compare productivity indices built up from the important performance traits on both an individual animal and a herd basis. The high output per unit mass that may be achieved by the Orma Zebu crosses under suitable environmental conditions may improve the economic efficiency of the Maasai pastoralist of Olkiramatian and Shompole group ranches.

\section{ACKNOWLEDGEMENTS}

This work received financial support from the Department for International Development. The assistance of the KETRI technical staff based at the Nguruman field station in animal handling and data collection is greatly appreciated. The cooperation by Maasai pastoralists in offering their animals was of great importance, while Patrick Irungu of KETRI assisted in data analysis. This work is published with the permission of the Director KETRI.

\section{REFERENCES}

AKOL, G.W.O., AUTHIE, E., PINDER, M., MOLOO, S.K., ROELANTS, G.E. \& MURRAY, M. 1986. Susceptibility and 
immune response of Zebu and taurine cattle of West Africa to infection with Trypanosoma congolense transmitted by Glossina morsitans centralis. Veterinary Immunology and Immunopathology, 11:361-373.

DARGIE, J.D., MURRAY, P.K., GRIMSHAW, W.R.P. \& MCINTYRE, W.I.M. 1979. Bovine trypanosomiasis: The red cell kinetics of N'Dama and Zebu cattle infected with Trypanosoma congolense. Parasitology, 78:271-286.

D'IETEREN, G. 1994. Trypanotolerant livestock, a sustainable option for increasing livestock production in tsetse-affected areas, in Towards increased use of trypanotolerance: Current research and future direction, edited by G.J. Rowlands \& A.J. Teale. Proceedings of a workshop organised by ILRAD and ILCA, Nairobi, Kenya, 1993.

D'IETEREN, G.D., AUTHIE, E., WISSOCQ, N. \& MURRAY, M. 1998. Trypanotolerance, an option for sustainable livestock production in areas at risk from trypanosomosis. Review of Science and Technology 17:154-175.

FAO/WHO/OIE. 1982. Animal health yearbook 1981, No. 18, edited by V. Kouba. Rome, Italy: FAO.

IRUNGU, P., NYAMWARO, S., ALUSHULA, H., REGE, E.O. \& DOLAN, R.B. 1999. Cattle keeping practices amongst Orma pastoralists: A household survey in Tana River District, Kenya, in Proceedings of the $25^{\text {th }}$ International Scientific Council for Trypanosomiasis Research and Control, Mombassa, Kenya, edited by K.R. Sones.

JORDAN, A.M. 1986. Trypanosomiasis control and African rural development. London: Longman.

MACLENNAN, K.J.R. 1980. Tsetse transmitted trypanosomiasis in relation to the rural economy in Africa: Part I. Tsetse infestation. World Animal Review, 36:2-17.

MCDERMOTT, J.J., RANDOLF, T.F. \& STAAL, S.J. 1999. The economics of optimal health and productivity in smallholder livestock systems in developing countries. OIE Review, 18: 399-424.

MURRAY, M. \& URQUHART, G.M. 1977. Immunoprophylaxis against African trypanosomiasis, in Immunity to blood parasites of animals and man edited by L.H. Miller, J.A. Pino \& J.J. McKelvey Jr. New York: Plenum Publishing Corporation.

MURRAY, M., TRAIL, J.C.M. \& D'IETEREN, G.D.M. 1990. Trypanotolerance in cattle and prospects for the control of try- panosomiasis by selective breeding. Review of Science and Technology, 9:369-386.

MURRAY, M., STEAR, M.J., TRAIL, J.C.M., D'IETEREN, G.D.M., AGYEMANG, K. \& DWINGER, R.H. 1991. Trypanosomiasis in cattle. Prospects for control, in Breeding for disease resistance in farm animals, edited by J.B. Owen \& R.F.E. Axford. Wallingford: $C A B$ International.

MWANGI, E.K., STEVENSON, P., GETTINBY, G., REID, S.W.J. \& MURRAY, M. 1998. Susceptibility to trypanosomosis of three Bos indicus cattle breeds in areas of differing tsetse fly challenge. Veterinary Parasitology, 79:1-17.

NJOGU, A.R., DOLAN, R.B., WILSON, A.J. \& SAYER, P.D. 1985. Trypanotolerance in East African Orma Boran cattle. The Veterinary Record, 117:632-636.

PALING, R.W., MOLOO, S.K., SCOTT, J.R., GETTINBY, G., MCODIMBA, F.A., LOGAN-HENFREY, L.L., MURRAY, M. \& WILLIAMS, D.J.L. 1991. Susceptibility of the N'Dama and Boran cattle to sequential challenges of tsetse transmitted clones of Trypanosoma congolense. Parasite Immunology, 13:427-445.

PEREGRINE, A. 1994. Chemotherapy and delivery systems: haemoparasites. Veterinary Parasitology, 54:223-248.

SWALLOW, B.M. 1997. Impacts of trypanosomosis on African agriculture. Proceedings of the $24^{\text {th }}$ International Scientific Council for Trypanosomiasis Research and Control, Maputo: 515-536.

TRAIL, J.C.M., SONES, K., JIBBO, J.M.C., DURKIN, J., LIGHT, D.E.\& MURRAY, M. 1985. Productivity of Boran cattle maintained by chemoprophylaxis under trypanosomiasis risk. Research Report No. 9. Addis Ababa, Ethiopia: ILCA.

TRAIL, J.C.M., D'IETEREN, G.D.M., MURRAY, M. 1991. Practical aspects of developing genetic resistance to trypanosomiasis, in Breeding for disease resistance in farm animals, edited by J.B. Owen \& R.F.E. Axford. Wallingford: CAB International.

WILSON, A.J., GATUTA, G.M., MGUTU, S.P. \& ALUSHULA, H. 1986. A simple epidemiological method for animal trypanosomiasis to provide relevant data for effective financial decision making. Veterinary Parasitology, 20:261-274.

WINROCK INTERNATIONAL. 1992. Assessment of animal agriculture in sub-Saharan Africa. Morrilton, Arkansas: USA, Winrock International Institute for Agricultural Development. 